\title{
COOPERATION AND NETWORKING IN METROPOLITAN AREAS FROM COMMUNITY OF PROBLEMS TO COMMUNITY OF COMMON INTERESTS IN THE WARSAW METROPOLITAN AREA
}

\author{
MIROSŁAW GROCHOWSKI \\ Institute of Geography and Spatial Organization \\ Polish Academy of Sciences \\ Twarda 51/55, 00-818 Warszawa, Poland \\ e-mail: mgrochow@twarda.pan.pl
}

\begin{abstract}
Since 1990, Polish municipalities have exercised planning power in terms of deciding on the ways of their economic and spatial development. Results of dynamic and sometimes uncontrolled, spontaneous development processes cross the borders of municipalities bringing problems, that can not be addressed, and solved by one municipality. Polish legislation provides legal basis for cooperation of municipalities: they may establish common goals' unions and associations in order to deal with problems that are important for more than one municipality. However, experience of the last several years proves that cooperation among municipalities is not an easy task. It creates problems especially within functional urban areas, including metropolitan ones. In this paper, the issue of cooperation among municipalities from the Warsaw Metropolitan Area (WMA) is addressed using the perspective of networking and formulation of common development policy.
\end{abstract}

Key words: intermunicipal cooperation, metropolitan areas, networking, management of urban development

\section{INTRODUCTION}

Cooperation among municipalities is a phenomenon that can be found in many countries. This cooperation varies in terms of scope and forms. The variety of scope and forms, as well as reasons and results of cooperation, depends to a large extent on three factors: legal regulations (public administration system that sets rules governing relationships among tiers of governance, tasks and responsibilities of specific tiers 
of governance, and their competencies to establish cooperation with private entities), characteristics of the area that municipalities are located in, and tradition and experience concerning inter-municipal cooperation that create specific "cooperation culture". The most interesting problem is inter-municipal cooperation in metropolitan areas. This cooperation is one of the possible institutional arrangements to manage metropolitan areas development (Hulst, and van Montfort 2007; Lackowska 2009; Brown 1992).

International experience indicates four main approaches to solving problems of metropolitan areas development. The first radical approach involves territorial reform. Municipalities are amalgamated into bigger administrative unit of self-government. The second approach is based on a concept of redistribution of the responsibilities between the different levels of government. The third approach is the involvement of privately and publicly owned companies and organizations in the fulfilment of public tasks by municipalities. The fourth approach is inter-municipal cooperation. The first two approaches are unpopular among municipalities because they lose their autonomy, responsibilities and powers (or they disappear from the administrative map entirely). The last one: inter-municipal cooperation is probably the most attractive solution for municipalities. Inter-municipal cooperation is tempting and promising because it creates conditions for delivery of public services, that meets the demands of the citizens at the low (lower or the lowest possible) costs. It also creates institutional environment to regulate the externalities of local policies. At the same time it leaves the policy domain of local government intact because there is no permanent transfer of local competencies and this is probably the main reason of the inter-municipal cooperation attractiveness. Additionally, inter-municipal cooperation does not require changes in the administrative organization of the state. It is much easier to adapt inter-municipal cooperation to changing development circumstances that bring new challenges for selfgovernments.

However, it has to be mentioned here that inter-municipal cooperation makes the system of management more complicated. It involves more decision makers and lacks hierarchical provisions to get out of deadlock situations. Democratic control of self-governments activities might also be hampered. More complex management structures and possibly more bureaucracy may increase costs of public administration operation but do not guarantee that governance in metropolitan area will be more effective (Lefevre 1998; Nunes and Barlow 2002; Herschell and Newman 2002; Hulst and van Montfort 2007).

There are two different types of tasks involved in inter-municipal cooperation: operational and coordination tasks. Operational tasks refer to delivery of public services; coordination tasks refer to the regulation of externalities of local policies and to an allocation of resources and costs that is rational from a sub-regional perspective. Operational tasks seem to be "politically neutral" and relations among municipalities that decided to cooperate to deliver services together are not "invasive" 
like in the case of coordination tasks, when reaching consensus is sometimes challenging.

Problems related to functional urban areas development in Poland have become more burdensome and noticeable over the period of the last two decades. These problems have been brought by dynamic economic development processes in the country after systemic changes that started in 1990. Bankruptcy of the centrally planned economy and political changes created new environment for economic and social development. Some urban agglomerations, among them Warsaw, acquired metropolitan functions and formed metropolitan areas. Firms and population are more mobile and proactive looking for the best location in space, which meets their needs and expectations. Most often they find these locations within metropolitan areas. Ongoing suburbanization and urban sprawl have impact on landscape, land use pattern, and new functional relationships among municipalities located within metropolitan areas. The case of the Warsaw Metropolitan Area (WMA) was chosen for analysis of inter-municipal cooperation because of two reasons. The first one is that the central city of the WMA is Warsaw - the capital city of Poland and the most dynamic urban centre in the country, which attracts migrants and firms both from Poland and from abroad. Migrants looking for jobs often settle in municipalities surrounding Warsaw, which offer lower costs of living. Big shopping centres and numerous firms chose also this location. It triggered changes in land use pattern and increased the scale of commuting as well as number of regular travels to service centres. The second reason is that although a need for coordinated development of metropolitan areas in Poland has been articulated many times by representatives of public authorities from different tiers of administration, there are no evidences (except declarations) of any changes in approaches to and the practice of metropolitan areas development in terms of legal regulations or any other activities initiated by the central government. Thus, municipalities from metropolitan areas have to deal with their problems looking for different mechanisms and instruments including cooperation with other municipalities.

\section{MAIN CHARACTERISTICS AND DEVELOPMENT CHALLENGES OF THE WARSAW METROPOLITAN AREA}

The Warsaw Metropolitan Area is located in the Mazovian region (mazowieckie voivodeship). This is the largest voivodeship in Poland in terms of area and population (area: 35 598/km² - 11.4\% of the Polish territory; 5 millions inhabitants (13.1\% of population of Poland). The City of Warsaw has 1,7 millions inhabitants (population density: $3291 / \mathrm{km}^{2}$ ); with the neighbouring municipalities that compose Warsaw Metropolitan Area approximately 3 million (population density: 474/ $\mathrm{km}^{2}$ ). The area of the WMA is $6205 \mathrm{~km}^{2}$; area of Warsaw is $517 \mathrm{~km}^{2}$. The WMA consists 
of 72 municipalities. The City of Warsaw is the richest municipality in Poland but one may also find in the voivodeship as well as in the WMA poor rural municipalities (Figure 1) $)^{1}$.

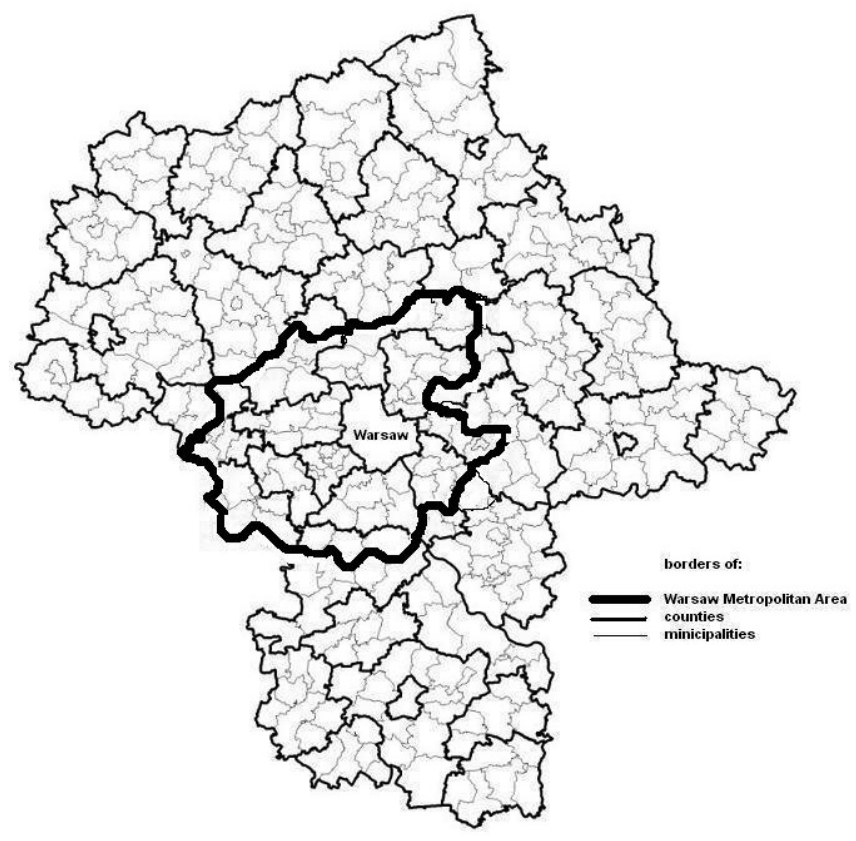

Figure 1. Warsaw Metropolitan Area within the mazowieckie voivodeship

The main development challenges of the WMA are:

- polarization of development: Warsaw is a growth pole of the mazowieckie voivodeship and the WMA. Polarization brings urban pressure to municipalities which posses the best environmental conditions (open spaces, forests, valuable land for agricultural production) and that are attractive for potential settlers,

- "dual-mode" development that leads to rising inequalities in the level of economic development and quality of life of population in urbanized and rural areas, and triggers migrations to urban centre (Warsaw) and / or surrounding municipalities,

- poorly developed transportation infrastructure,

- lack of economic, social, and territorial cohesion,

- urban sprawl that contributes to spatial chaos,

- rising complexity of functional pattern of the WMA with a lack of sub-regional development strategy and cohesive spatial policy,

\footnotetext{
1 The WMA border was delineated by the Mazovian Office for Regional Planning in Warsaw. This delineation shall be considered as an official one and prepared for practical purposes of spatial planning and management of development of the area. The main characteristics of the WMA are presented in the publication Obszar Metropolitany Warszawy (Warsaw Metropolitan Area) published by the Mazovian Office for Regional Planning and Main Statistical Office in 2008.
} 
- lack of mechanism of coordination of development efforts designed and implemented by municipalities (Grochowski 2009; Strzelecki 2009).

The WMA shall be a subject of planning activities. The Spatial Planning and Land Management Act of 27th March 2003 calls for the first time in Polish history of spatial planning for preparation of the Spatial Development Plans for Metropolitan Areas. This is the regional self-government which is obliged by the law to prepare this plan. This responsibility implies what entity shall be in charge of the management of the metropolitan area development. However, it is not clearly stated in the legislation regulating responsibilities of different tiers of self-government. Regional selfgovernment is also obliged to prepare the Strategy for Regional Development and the Regional Spatial Development Plan for the voivodeship. All these documents must be coherent and shall be reviewed, and evaluated periodically, and amended if needed. Regional development programs must result from the Strategy for Regional Development and be coordinated with the guidelines incorporated in the Regional Spatial Development Plan. However, since 2003 no spatial development plan for metropolitan area in Poland has been enacted. Legislative inconsistencies impeded preparation and / or enactment of these plans. It also concerns the plan for the WMA. Additionally, there is no political agreement on who and how shall manage development of metropolitan areas in Poland. A bill called "metropolitan law" is still under preparation and one may doubt whether disputes on management mechanisms and instruments will be concluded in the period of next months or years. Thus, the challenges listed above can not be addressed under new legal framework that may impose necessary solutions in terms of instruments to be used or additional competencies ascribed to old or new tier of public administration. In this situation cooperation among municipalities seems to be the only available solution to guide development processes in the WMA (Grochowski 2008).

\section{INTER-MUNICIPAL COOPERATION IN THE WMA}

The goal of the study conducted was to identify cases of inter-municipal cooperation in the WMA that contribute to its sustainable development. Since there are different connections and relationships among municipalities it was decided that two criteria must be met to recognize interactions among municipalities as an inter-municipal cooperation. These criteria were:

a) interactions between municipal governments concerned a common goal, and

b) interactions between municipal governments were institutionalized. It was also decided that interactions among municipalities could be accompanied by involvement of authorities form different tiers of public administration and / or involvement of private sector organizations.

According to the data from the Ministry of Internal Affairs and Public Administration there are 17 common goals inter-municipal unions operating in the mazowieckie 
voivodeship and one association (Metropolitan Warsaw Association) with ambition to facilitate cooperation among municipalities in the region ${ }^{2}$ (as of December 31st 2009). There are 6 common goals inter-municipal unions that operate in the WMA and there are 35 municipalities altogether involved in these cooperative agreements (out of 72 that constitute the WMA). The smallest union consists of 3 municipalities, the biggest one of 8 municipalities. Metropolitan Warsaw Association has 25 member municipalities and is supported by a group of 14 associated member municipalities.

Municipalities from the WMA are also members of nationwide self-government organization: 5 municipalities are members of the Union of Small Towns, 16 municipalities of the Union of Polish Cities, 20 municipalities of the Union of Rural Municipalities. The nationwide self-government organizations are corporate organizations that represent interests of specific categories of municipalities on national an international forum. As such their activities are not focused on territorial dimension of municipalities' activities but rather on the initiatives supporting functioning of member municipalities (including different programs and projects dedicated to members of associations and lobbying for changes of legal framework they operate in).

Analysis of statutory documents, plans, and programs implemented by inter-municipal unions operating in the WMA allows to state, that the scope of their activities is differentiated. The most popular theme of cooperation is protection of natural environment resources. Content of this theme is very capacious and some activities are of a "soft" nature (public awareness campaigns). Improvement of the sewage system conditions also fits this label. The second broad area of cooperation is the maintenance and development of technical infrastructure (waterworks, sewage systems, roads). There are also examples of specific issues that bring together municipalities (shelters for homeless dogs, slaughter waste, gathering point). There is only one inter-municipal union that listed in the statutory documents the task of spatial planning (Table 1). Thus inter-municipal cooperation unions from the WMA are organizational arrangements of multi-purpose character. With one exception these unions are focused on operational tasks. In case of Communal Union "NOVELTY" a company was established to coordinate activities related to the construction of the cargo airport. In other cases different undertakings are coordinated jointly by municipalities. Standing organization is not popular solution. It is characteristic, that unions are institutionalized through agreements and networking. This is because of the size of unions and scale of their activities. In small and accountable organization reaching consensus is relatively easy.

Intensity of activities undertaken by inter-municipal unions varies in time. The most stable and regular is cooperation which concerns issues important for all members of the union, issues connected with delivery of public services of different types, and which involves municipalities' financial resources. The importance of inter-municipal cooperation for development activities of their members can not

\footnotetext{
2 Polish legislation provides two different legal forms for organization of municipalities: unions and associations. From the practical perspective of managing development both are equally important.
} 
Table 1. Common goals inter-municipal unions operating in the WMA

\begin{tabular}{|c|c|c|c|}
\hline $\begin{array}{l}\text { Name of the union } \\
\text { and location of } \\
\text { headquarters }\end{array}$ & $\begin{array}{c}\text { Member } \\
\text { municipalities }\end{array}$ & Tasks & $\begin{array}{c}\text { Date of } \\
\text { establishment }\end{array}$ \\
\hline $\begin{array}{l}\text { Communal Union; } \\
\text { Brwinów }\end{array}$ & $\begin{array}{l}\text { Błonie, Brwinów, } \\
\text { Michałowice, } \\
\text { Milanówek, Piastów, } \\
\text { Ożarów Mazowiecki }\end{array}$ & $\begin{array}{l}\text { Natural environment } \\
\text { protection, recycling of } \\
\text { communal waste }\end{array}$ & 07/08/1991 \\
\hline $\begin{array}{l}\text { Communal Union } \\
\text { "NOVELTY"; } \\
\text { Zakroczym }\end{array}$ & $\begin{array}{l}\text { Nowy Dwór } \\
\text { Mazowiecki, } \\
\text { Pomiechówek, } \\
\text { Zakroczym }\end{array}$ & $\begin{array}{l}\text { Activities concerning } \\
\text { transportation, } \\
\text { telecommunication, housing } \\
\text { construction, construction } \\
\text { of the airport "Modlin } \\
\text { Cargo", natural environment } \\
\text { protection, development of } \\
\text { infrastructure for tourism, } \\
\text { sport, and recreation, } \\
\text { health care }\end{array}$ & 07/08/1991 \\
\hline $\begin{array}{l}\text { Inter-municipal } \\
\text { Union "Warsaw } \\
\text { union of waterworks } \\
\text { and drainage", } \\
\text { Warsaw }\end{array}$ & $\begin{array}{l}\text { Warszawa, } \\
\text { Michalowice, } \\
\text { Piastów, Ożarów } \\
\text { Mazowiecki, Ząbki }\end{array}$ & $\begin{array}{l}\text { Water supply, drainage } \\
\text { system maintenance, sewage } \\
\text { treatment }\end{array}$ & $20 / 11 / 2000$ \\
\hline $\begin{array}{l}\text { Inter-municipal } \\
\text { Union "Kampinos", } \\
\text { Kampinos }\end{array}$ & $\begin{array}{l}\text { Brochów, } \\
\text { Kampinos, Leoncin, } \\
\text { Leszno, Łomianki, } \\
\text { Młodzieszyn }\end{array}$ & $\begin{array}{l}\text { Solid waste treatment, } \\
\text { water supply, maintenance } \\
\text { of drainage system, } \\
\text { maintenance of the road } \\
\text { system, investments in } \\
\text { education, culture, tourism, } \\
\text { sport, recreation, health } \\
\text { care, development of public } \\
\text { transportation }\end{array}$ & $25 / 06 / 2001$ \\
\hline $\begin{array}{l}\text { Inter-municipal } \\
\text { Union "Western } \\
\text { Mazovia", } \\
\text { Mszczonów }\end{array}$ & $\begin{array}{l}\text { Baranów, Jaktrorów, } \\
\text { Mszczonów, } \\
\text { Puszcza Mariańska, } \\
\text { Radziejowice, } \\
\text { Teresin, Wiskitki, } \\
\text { Żabia Wola }\end{array}$ & $\begin{array}{l}\text { Coordination of activities } \\
\text { related to spatial planning, } \\
\text { natural environment } \\
\text { protection, mutual ownership } \\
\text { of shelters for homeless dogs, } \\
\text { slaughter waste gathering } \\
\text { point }\end{array}$ & $21 / 11 / 2002$ \\
\hline $\begin{array}{l}\text { Union of } \\
\text { Municipalities } \\
\text { of "Zegrzyński } \\
\text { Reservoir", } \\
\text { Legionowo }\end{array}$ & $\begin{array}{l}\text { Dąbrówka, } \\
\text { Jabłonna, } \\
\text { Legionowo, } \\
\text { Nieporęt, Radzymin, } \\
\text { Serock, Wieliszew, }\end{array}$ & $\begin{array}{l}\text { Protection of natural } \\
\text { environment resources } \\
\text { around the Zegrzyński } \\
\text { Reservoir, construction } \\
\text { and modernization of } \\
\text { water supply system, water } \\
\text { treatment, sewage treatment, } \\
\text { solid waste collection system, } \\
\text { development of tourism }\end{array}$ & $30 / 03 / 2004$ \\
\hline
\end{tabular}


be questioned. However, it shall be noticed, that all unions cover with their activities relatively small areas. Thus from the perspective of development problems of the WMA and its sustainable development these unions play small role.

After analysis of documents describing the range and goals of activities of intermunicipal unions and association that function in the WMA the case of the Metropolitan Warsaw Association seemed to be different. The charter of the Metropolitan Warsaw Association states, that the main goal of the Association is to support territorial self-governments of the Warsaw Metropolitan Area in their efforts to secure sustainable development of their territories and the territory of the WMA area (Statut 2006; Statut 2009). The main goal of the Association shall be achieved through a number of different activities. Among them are:

a) initiation and support for activities focused on new legislative solutions which will facilitate functioning of self-government of Warsaw, especially in the domain of spatial planning, constructing efficient public transportation system, development of technical infrastructure, public safety, natural environment protection, development of cultural and educational services as well as social assistance and health care systems;

b) development of initiatives and activities that will contribute to integration of the metropolitan self-government community,

c) technical assistance offered to the members of the Association in solving development problems,

d) protection of rights and interests of member municipalities on the regional and national forum,

e) mediations in case of conflicts between member municipalities,

f) technical assistance in establishing agreements, common purpose unions, and companies to execute public tasks,

g) identification of specific needs and circumstances of the WMA development.

The first activity is of special importance for the WMA development. In order to manage development of functionally integrated area development's vision translated into development strategy and coordination of planning and implementation activities are needed. In-depth research was conducted in order to learn more about the work and results of the Metropolitan Warsaw Association activities. The in-depth research consisted of two stages. In the first stage a questionnaire was distributed among members of the Association to collect opinions on perception of development problems, approaches and methods of solving them, and assessment of the current situation in the WMA in terms of relationships among municipalities. In the second stage interviews with members of the Board of the Association were conducted. The interviews' topics covered also the history of the Association's activities, which provided information about the dynamics of the political processes related to establishment and functioning of the Association.

The Metropolitan Warsaw Association is a result of a grass-root initiative of local leaders from municipalities of the WMA. The Association was established in the year 
2000 but was legally registered in April 2004. In the year when the Association was established the City of Warsaw had a legal form of an obligatory union of 11 municipalities. Mayors of Warsaw's municipalities and municipalities neighbouring Warsaw institutionalized their cooperation efforts through establishment of the Association. The central municipality of Warsaw (municipality Centrum with more than 1 million inhabitants) which could in fact function in isolation like an "island of wealth" having big and stable tax revenues, still available attractive for investors land for development, well developed social and technical infrastructure was not motivated to join the group. During the first two years of functioning of the Association the Centrum municipality was passive although there were several attempts to convince the mayor of the municipality Centrum that cooperation would be beneficial for all municipalities including the Centrum municipality and the WMA itself. Other municipalities exercised building development coalition for the area: informal contacts and networking served as a vehicle to coordinate development plans.

In the year 2002 the legal status of the City of Warsaw changed. Since then Warsaw is one municipality divided into 18 districts with limited competencies and powers. The justification of the change of administrative structure was that administrative fragmentation of the city hampered its development and made coordination of development undertakings within the city border impossible. According to opinions presented by the members of the Board of Association, Warsaw - as one big municipality with population of 1.7 million people and the central city of the WMA - was not interested in cooperation with neighbouring municipalities. Selfgovernment of Warsaw did not show interests in the concept of Warsaw as a leader of the metropolitan area. The understanding of importance of integrated approach to development of big urban areas like Warsaw and surroundings among politicians responsible for managing Warsaw development was low. Dynamics of uncoordinated development processes of Warsaw and surrounding municipalities started to become a reason of accumulating problems. With a lack of political will and legal obligations to cooperate and with no any other regulations concerning metropolitan areas development, the whole territorial system functioned as fragmented one. Seeing this, the founders of the Association decided to formalize its existence and registered the Association in the court in 2004 to give new incentives for its activities.

Eventually Warsaw joined the Association in the year of 2006 when the new Warsaw's self-government was elected. The year 2006 can be seen as a new opening in the activities of the Association. It was decided to establish four working groups dealing with issues crucial for development of member municipalities of the Association: group on spatial planning and administrative organization, group on communal services, group on transportation development, and group dealing with programmatic issues of the Association's activities. The Association initiated nationwide discussion on metropolitan areas' legal status and possible managerial arrangements. With the Association support the bill on metropolitan areas was drafted in 2008. The Association started nationwide debate on how to manage metropolitan areas 
development. However, it turned out that perception of the "metropolitan issue" presented by Warsaw and other member municipalities were different. The cooperation was not smooth. Meetings of the working groups were not regular and their results hardly visible. There were some conferences and working meetings organized by the Association to lobby for proposed solutions for metropolitan areas legal organization or for solutions of specific problems. However, results of these events were not translated into tangible results. The only exception was an initiative to introduce in the WMA so called "common ticket". This initiative was successfully materialized in 2009. The "common ticket" was introduced for the area called Warsaw Agglomeration. This area is smaller than the delineated area of the WMA. However, the "common ticket" shall be considered as a success of the Association: commuters within the Warsaw agglomeration can travel now with one ticket using means of transportation operated by different companies that are owned by or subordinated to different authorities.

In 2008 Ministry of Internal Affairs and Public Administration started work on legislation on metropolitan areas. At the same time the Association of Metropolitan Cities (AMC) - nationwide corporate organization grouping the biggest Polish cities $^{3}$ - started to lobby for its proposal of management scheme for metropolitan areas. The AMC proposed to establish metropolitan counties - a form of obligatory grouping of municipalities. The bill prepared by the Metropolitan Warsaw Association proposed voluntary union of municipalities as a legal form of metropolitan area organization. These two proposals were contradictory. Additionally in 2009 representatives of regional self-governments prepared another proposal on how to manage metropolitan areas development. The proposal contained different solution than those from the three other proposals listed earlier. In 2009 the nationwide debate focused on one proposal - this prepared by the Ministry of Internal Affairs and Public Administration. However, the essence of the matter was merely present in this debate. Discussion were dominated by two issue: how to divide power (who will be the head of the "metropolitan government") and how many metropolitan areas shall be legally established in Poland. For many cities it has become a question of political ambition to be recognized as a metropolitan city. The debate has become deeply politicized which could be seen reading new versions of the debated draft legislation. The number of metropolitan areas arose from initial two to seven and then to sixteen and subsequently dropped to three and then again to two metropolitan areas.

Warsaw did not actively participated in this debate. This fact placed the Association in an awkward position. Eventually, at the beginning of 2010 the debate was "hibernated". The reason for that was that in the autumn of 2010 elections to selfgovernments will be organized in Poland and the "metropolitan issues" is politically risky issue for many politicians regardless whether they are active at local, regional or national political scene. It also seems that the Association after ten years of existence became "hibernated" - the Association did not manage to realize its main goals.

\footnotetext{
3 Warsaw is a member city of the AMC
} 
Warsaw as a member of the Association did not strengthen the Association. Warsaw did not become a lobbyist supporting new approaches to metropolitan areas development. It also seems that Warsaw still has very little interest in cooperation with municipalities form the WMA.

Despite the failures and inefficiency of different efforts to bring together municipalities from the WMA the idea of the inter-municipal cooperation has not disappeared. In fact, it could not disappear because development conditions have not changed and development challenges are still in place. Based on the results of the in-depth analysis it might be stated that the need and support for cooperation among municipalities within the WMA are definitely strong. Functional relationships among municipalities and willingness to cooperate shall serve - according to respondents' opinions - as criteria for delineation of the metropolitan area. This is a very practical approach to cooperation. Municipalities are looking for partners in solving their problems. More than $70 \%$ of respondents stated, that based on their up-to-date experience, additional management structure is needed to facilitate intermunicipal cooperation. Establishment of additional management structure means very often reduction of competencies of municipalities and this fact is accepted by $43 \%$ of respondents ( $43 \%$ answered: rather yes and $14 \%$ definitely no). Local perspective on development dominates among municipalities, however metropolitan dimension is also seen by respondents (Figure 2).

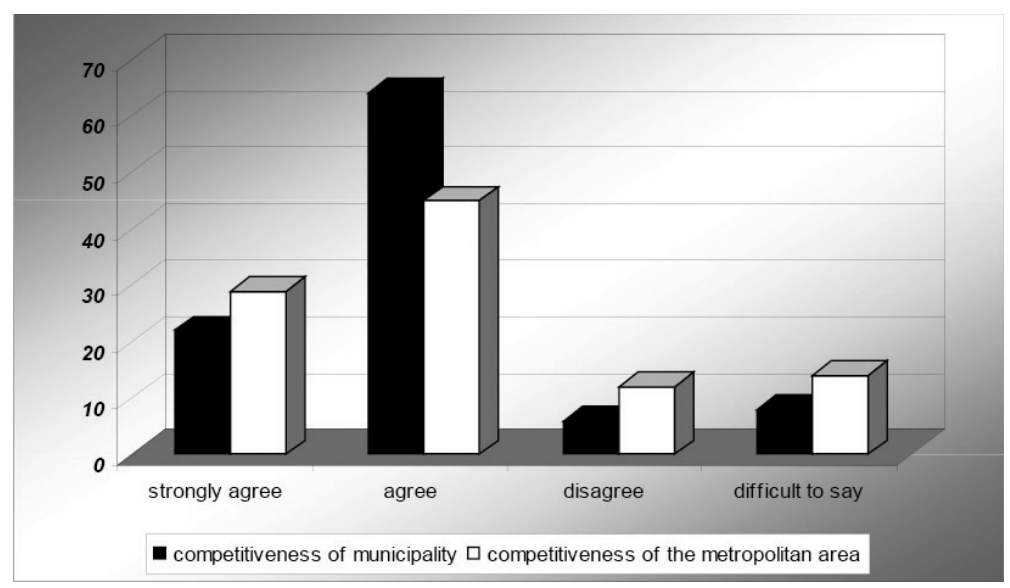

Figure 2. Main goals of municipalities' development policies

The results of the analysis also indicate, that thinking about solving current problems is more common than thinking about systemic, long-term, and future oriented solutions (Figure 3). Most respondents indicates, that transportation problems are crucial for development of the WMA. At the same time the number of those who see spatial planning coordination as a key issue for sustainable development of the WMA is relatively low. Improper spatial arrangements may trigger migrations and increase pressure on transportation system. In a long-term perspective uncoordinated location of functions within functionally integrated area will contribute to accumulation 
of problems. The approach presented by municipalities is typically reactive one. It may result from two reasons. The first one is that the problems with transportations are so severe that immediate intervention is needed. Otherwise the system will lose its functionality. The second reason might be a lack of trust in efficiency of spatial planning as an instrument of intervention. Thus, concrete investments in transportation infrastructure seem to be the best and pragmatic solution.

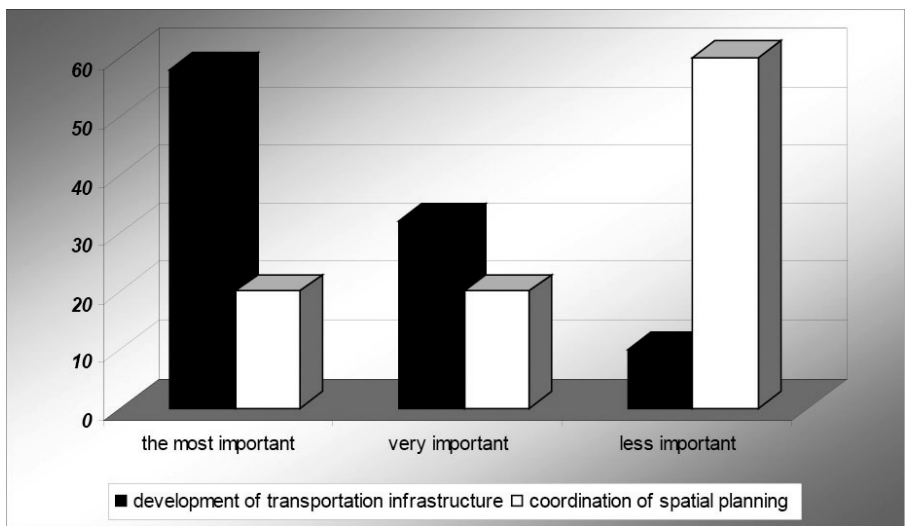

Figure 3. Assessment of importance of development of transportation infrastructure and of coordination of spatial planning for development of the WMA

As was mentioned above the national debate on the "metropolitan law" was dominated by the issue of who should have power to decide about development of metropolitan area. Results of the study allow to draw conclusion, that "balance of power" is important. However, the most important is "human factor" - openness for cooperation and ability to reach consensus (answers: the most important and very important) (Figure 4).

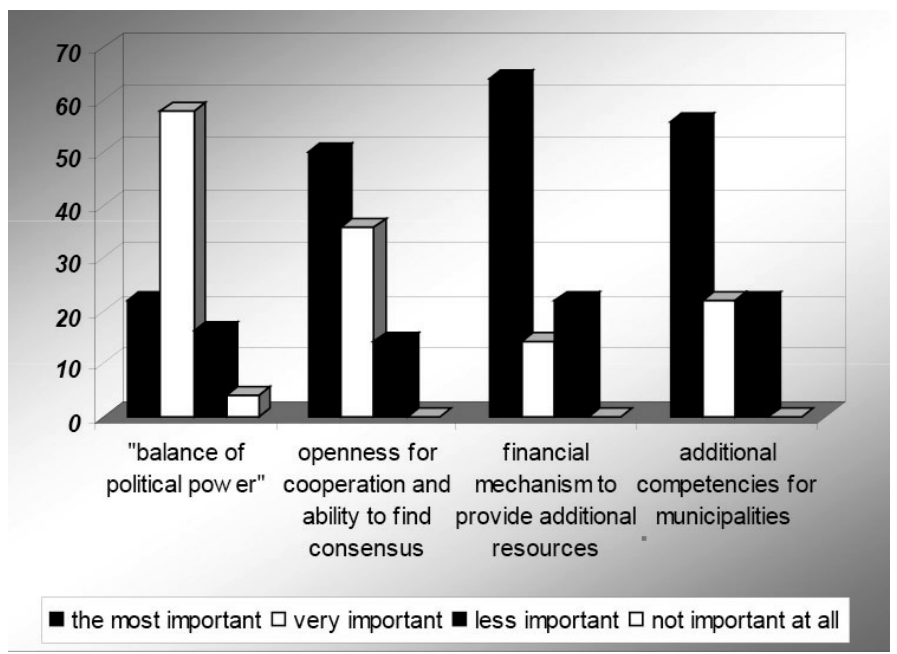

Figure 4. Assessment of issues important for cooperation among municipalities 
Respondents stated that the most important factors that would contribute to smooth cooperation among municipalities were: clear division of competencies and identification of common goals. The preferable legal form of organization of the WMW was voluntary union of municipalities supported by additional management structures to manage delivery of specific services.

\section{CONCLUSIONS}

It might be anticipated, that the dynamic development of the WMA will continue (Grochowski et al. 2005; Grochowski 2009; Lisowski 2005). It may deepen current problems and have negative impact on functionality of the territorial system of the WMA. Since there are no legal regulations concerning development of metropolitan areas in Poland inter-municipal cooperation seems to be an important and in fact the only one instrument that can be used to deal with development problems. However, results of the study prove, that inter-municipal unions and association that operate in the WMA are not able to solve problems of key nature for the WMA and secure conditions for its sustainable development.

It might be stated that most unions focus their activities on operational tasks. These are problems that bring together these municipalities not common interests seen in a long-term perspective. Focusing on operational tasks is not enough. The issues of the regulation of externalities of local policies is not addressed. Declarations expressed by members of the Metropolitan Warsaw Association are promising but still activities of the Association have a character of "symbolic policy making" with no practical results (except "common ticket").

Composition of the inter-municipal unions proves that both pure inter-municipal cooperation and mixed arrangements (with other partners) are exercised. The degree of institutionalization is low, but the members of unions maintain contacts with each other on a regular basis. There are different scopes of activities of inter-municipal unions from the WMA. However, there is a lack of union that covers the whole WMA and deal with coordination tasks. Lack of tradition of intermunicipal cooperation, lack of a leader, and passive approach of Warsaw to contacts with municipalities from the WMA are the most important reasons of the current situation in terms of inter-municipal cooperation within the WMA. Inter-municipal cooperation is not the perfect instrument to govern development of the WMA but the lack of it-currently the only one available instrument - may result in spatially and functionally chaotic development processes, which will have negative impact on economic performance of the WMA, quality of life of its inhabitants, and quality of natural environment. 


\section{REFERENCES}

Brown, M.P. (1992), The possibility of local autonomy, Urban Geography, 13, 257-279.

Grochowski, M. (2008), Analysis of regional spatial planning and decision making strategies and their impact on land use in the urban fringe; Case study: Warsaw Metropolitan Area, Poland; Report: VI FP UE: Peri-Urban Land Use Relationships - Strategies And Sustainability Assessment Tools For Urban-Rural Linkages, Integrated Project, Warsaw.

Grochowski, M. (2009), Samorząd terytorialny a rozwój zrównoważony obszarów metropolitalnych (Self-government and sustainable development of metropolitan areas), Mazowsze, Studia Regionalne, 2, Mazowieckie Biuro Planowania Regionalnego, Warszawa.

Grochowski, M., Fuhrmann, M., Pieniążek, M., Wilk, W. Zegar, T. (2005), Warszawa Obszar Metropolitalny Warszawy-Mazowsze; Relacje międzygminne: współpraca czy obojętność; (Warsaw - the Warsaw Metropolitan Area - Mazovian region: Inter-municipal relations: cooperation or neutrality), Samorząd Terytorialny, 7-8, Wyd. Kik, Oddział Wydawnictw Profesjonalnych Sp. z o.o., Warszawa.

Herschell, T. and Newman, P. (2002), Governance of Europe's city regions: Planning, policy, and politics, Routledge, London.

Hulst, R. and van Montfort, A. (eds.) (2007), Inter-municipal cooperation in Europe, Springer, Dordrecht.

Lackowska, M. (2009), Zarządzanie obszarami metropolitalnymi w Polsce (Management of metropolitan areas in Poland), Wyd. UW, Warszawa.

Lefevre, C. (1998), Metropolitan government and governance in western countries: A critical review, International Journal of Urban and Regional Research, 22 (1), 9-25

Lisowski A. (2005), Urban sprawl process, in: Gutry-Korycka M. (ed.) Urban sprawlWarsaw Agglomeration Case Study, Wyd. UW, Warszawa.

Nunes, S.C. and Barlow, M. (2002), Developments in the government of seven European metropolitan areas, GeoJournal, 58 (special issue), 1-72.

Statut Stowarzyszenia Metropolia Warszawa 2006, (and changed in 2009), Warszawa. Strzelecki, Z. (2009), Mazowiecki wymiar polityki rozwoju, in: Rzeźnik G. (ed.) Polityka regionalna na Mazowszu, Polski Instytut Demokracji Lokalnej, FRDL, Warszawa, 15-35. 